$0.866 \mathrm{~mm}$. in length, the other $0.152 \mathrm{~mm}$, the former protruding $0.0172 \mathrm{~mm}$. beyond the cloaca, the latter retracted.

Previous observers have given the length of the short and long spicules as 130 and $170 \mu$ (sic!) respectively. In the above-mentioned specimen it will be observed the long spicule has attained a length five times that noted in the short."

There is considerable, variation in the measurements given by different authorities. Neumann describes the male as $8 \mathrm{~mm}$. and the female as $14-16 \mathrm{~mm}$. in length, which corresponds to the measurements given above for the specimen secured from man. Those from the dog are decidedly smaller, though the morphological features are apparently identical. The measurement of the males approximates to the figures given by Lingard. Consequently, until careful comparisons have thrown more light on the matter, the worms may be taken as varieties of $F$. palpebralis.

\title{
THELAZIASIS IN MAN : A SUMMARY OF RECENT REPORTS ON "CIRCUMOCULAR FILARIASIS" IN CHINESE LITERATURE, WITH A NOTE ON THE ZOOLOGICAL POSITION OF THE PARASITE
}

BY

\author{
R. T. LEIPER, M.B., D.SC.
}

HELMINTHOLOGIST TO THE LONDON SCHOOL OF TROPICAL MEDICINE.

IN the China Medical Journal of January, 1917, Dr. E. J. Stuckey $^{1}$ has recently brought under notice a new and interesting affection of the eye in man. A young yamen servant attended the eye clinic of the Union Medical College Hospital in Pekin, complaining that since the preceding summer there seemed to be a "worm" or "worms" in his right eye. He brought a bottle containing a small object, like a piece of white thread, which he said that he had removed from his eye two days before. Dr. Stuckey made a very careful examination, and an almost invisible body was seen moving in the upper fornix. After cocainization, "four white worms like threadworms, 8-13 $\mathrm{mm}$. long, were removed from the fornices." On the following day the patient removed a further specimen himself.

In a succeeding number of the same journal, Dr. C. G. Trimble $^{2}$ gave a more detailed account of a similar case in a Chinese farmer of Fukien. This patient had " what appeared at first sight to be a marked ectropion of the right eye and a slight ectropion of the left." The clinical history of this case is as follows: "Three months previously he had noticed a pain or ache 
in his right eye, slight at first, but becoming worse and worse, until at the time of coming to us he was in great discomfort. Shortly after the onset of the pain he noticed that he had an excessive flow of tears, and for the last month he had been unable to close his eye completely." " The most striking thing noticed upon superficial examination was the severe ectropion of the right lower lid, which was more of a sagging away of the lid than the usual type of ectropion. This allowed a constant flow of tears to run down his face. Further examination revealed that this sagging away was due to a more or less complete facial paralysis of the right side. There was only a slight conjunctivitis and we were about to dismiss the man as an incurable case of facial paralysis, when a more careful inspection of the conjunctival sac brought to light, in the superior fornix of the right eye, two small worms. They were decidedly active, pink in colour, and easily distinguished from the slightly congested conjunctiva. They were easily removed and further search for others in both eyes proved fruitless. Upon removal of the parasites the man had immediate relief as far as the pain was concerned. We had him under observation for about three weeks, during which time the epiphora disappeared and the muscle tone in the paralysed area was restored to at least 50 per cent. of the normal. The facial paralysis appeared to be due entirely to the parasitic irritation extending over the three months."

Dr. Trimble states that the worms were females of the same species as those found in Dr. Stuckey's case.

The Rev. T. Biggin found similar worms in the eyes of his pet dog at Tungchow and these, together with specimens from his own case, were sent by Dr. Stuckey to Dr. H. S. Houghton in Shanghai for report.

Dr. Houghton's "Note upon the filarial parasites from the conjunctival sac" $\left({ }^{3}\right)$ contains the following description of these worms :

Specimen from dog: Body filiform, cylindrical, white, attenuated at both ends, cuticle striated. Mouth terminal, small, unarmed; œsophagus short $(2 \mathrm{~mm}$.) and without a bulb. Anus subterminal. Male, $6 \mathrm{~mm}$. in length and 0.3 to $0.5 \mathrm{~mm}$. in breadth. Tail curved at right angles to axis of body but not coiled. Four pre-anal papillæ, and a small postanal projection. Female, larger and thicker than male, measuring 10 to $12 \mathrm{~mm}$. by $0.8 \mathrm{~mm}$. Vulvar opening close to anterior extremity. Uterine tubes crowded with eggs containing embryos.

Specimen from man: The morphology is much the same as in the worms described above. The specimens from the human eye, however, are distinctly larger, the female measuring 14 to $15 \mathrm{~mm}$., the male 9 to $10 \mathrm{~mm}$. in length, and the bodies being correspondingly thicker. 
The specimens, described above, are, in Dr. Houghton's opinion, varieties of Filaria palpebralis, Wilson, 1884, a nematode worm commonly affecting the eye of the horse.

\section{Zoological position}

The parasites are rightly considered by Dr. Houghton to be related to eye-worms found in equines and bovines. The parasites are now recognized to differ from Filaria worms in several important respects both as regards their morphology and development. A considerable number of species have been recorded within recent years from mammals and birds. They are now grouped by Railliet ${ }^{4}$ in three genera, viz.: Thelazia, Ceratospira, and Oxyspirura, in the family THELAZIIDÆ, which forms with the ACUARIIDE and SPIRURIDÆ, the important super-family SPIRUROIDEA.

All the forms found parasitic in the eyes of mammals are now confined to the genus Thelazia.

The two other genera contain the worms which live in the eyes of birds. In China, "Manson's eye-worm" is very common in chickens, but this belongs to the genus Oxyspirura, differing from the form described above for man in having a long sharp tail and in the position of the vulva, which lies just in front of the anus near the posterior end of the body.

Railliet recognizes ${ }^{4}$ altogether six species of thelazia as parasites in mammals, viz :-

1. Thelazia rhodesi (Desmarest, 1827) in Bos taurus and Buffelus bubalis.

2. Thelazia gulosa, Railliet and Henry, 1910, in Bos taurus.

3. Thelazia alfortensis, Railliet and Henry, 1909, in Bos taurus.

4. Thelazia leesei, Railliet and Henry, 1910, in Camelus dromedarius.

5. Thelazia lacrymalis (Gurlt, 1831) in Equus caballus (=Filaria palpebralis, Wilson, 1844).

6. Thelazia callipæda, Railliet and Henry, 1910, in Canis familiaris.

From the illustration accompanying Dr. Houghton's description ${ }^{3}$ it is clear that the parasites of "circumocular filariasis" in man belong to the genus Thelazia, and as they are said to correspond so closely to those found in the dog in the same part of the world there seems good ground for an assumption that they may be examples of the species Thelazia callibod $a^{5}$ which is apparently a common eye-worm in the dog in Asia, and was first recorded from the Punjab by Railliet and Henry ${ }^{5}$, in 1910.

In the number of papillæ and in a few other details the brief account of the human Thelazia does not tally exactly with $T$. lacrymalia or $T$. callipada. An emendation either of the 
description or of the diagnosis must result from a more detailed examination of the material.

\section{REFERENCES.}

I. Stuckey, E. J.-_"Circumocular Filariasis." China Med. Jl., Jan., I917.

2. Trimble, C. G,-_"Circumocular Filariasis." China Med. Jl., May, 1917, p. 266.

3. Houghton, H. S. - "Note upon Filarial Parasites from the Conjunctival Sac." China Med. Il., Jan., 1917.

4. Railliet, A._"La Famille des Thelaziidæ." The fl. of Parasitology, March, 1916, pp. 99-105.

5. Railliet and Henry. - "Nouvelles Observations sur les Thelazies." Compt. Rend. de la Sociêté de Biol., Bd., LXVIII, p. 783, I910.

\section{ANNOTATIONS}

\section{Cataract Extractions in the Old Days}

The records of successful extraction operations form a striking feature in the ophthalmic text-books of a hundred years ago. The veracity of the statements is, of course, open to doubt ; the results may not have been as they are described, and may for personal reasons have been embellished. But critically examined there does not appear, in this case, to be much room for suspecting a concealment of the truth. These records again are the more remarkable, having regard to the few circumstances prevailing at the time favourable to successful results. In the absence of local or general anæsthesia the operator was compelled to rely upon the fortitude of his patient; that fortitude must always have been of an uncertain quantity, introducing a speculative factor into each extraction operation, by no means conducive to the surgeon's peace of mind. In those days, however, the fortitude generally displayed can only excite our praise; patients were brave enough to submit to a double extraction, consecutively performed, which was the general rule. There was no question at that time of postponing the second extraction, in order to await the results of the first ; on the contrary, the risks of a consecutive operation were apparently lightly undertaken by the operator, and the double trial of fortitude as lightly tolerated by the patient. Again, the fact is especially noticeable that in the pre-antiseptic days of old septic reaction was very infrequent. Naturally, perhaps, nothing is to be gleaned from the old records suggestive of a toilette preparation of the hands, instruments, or dressings, to ensure cleanliness, or that, any belief prevailed that such precautions constituted a material factor in the results. Furthermore, ingenuity in the design of their instruments was decidedly lacking. In proof thereof some weird examples of eye instruments are to be found illustrated in 